\title{
INFLUENCE OF SEED LOADS ON START UP OF MODIFIED ANAEROBIC HYBRID BAFFLED (MAHB) REACTOR TREATING RECYCLED PAPER WASTEWATER
}

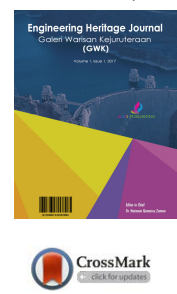

\author{
Siti Roshayu Hassan ${ }^{\mathrm{a}}$, Nastaein Qamaruz Zaman ${ }^{\mathrm{b}, \mathrm{c}}$, Irvan Dahlan ${ }^{\mathrm{c,d}}$ \\ a Faculty of Bioengineering and Technology, Universiti Malaysia Kelantan, Campus Jeli, Locked Bag No. 100, 17600, Jeli, \\ Kelantan, Malaysia. \\ ${ }^{b}$ School of Civil Engineering, Universiti Sains Malaysia, Engineering Campus, Seri Ampangan, 14300 Nibong Tebal, Pulau \\ Pinang, Malaysia.
}

'Solid Waste Management Cluster, Science and Engineering Research Centre, Universiti Sains Malaysia, Engineering Campus, Seri Ampangan, 14300 Nibong Tebal, Pulau Pinang, Malaysia.

${ }^{d}$ School of Chemical Engineering, Universiti Sains Malaysia, Engineering Campus, Seri Ampangan, 14300 Nibong Tebal, Pulau Pinang, Malaysia.

*Corresponding author email: chirvan@usm.my

This is an open access article distributed under the Creative Commons Attribution License, which permits unrestricted use, distribution, and reproduction in any medium, provided the original work is properly cited

\section{ARTICLE DETAILS}

\section{Article history:}

Received 5 June 2017

Accepted 15 August 2017

Available online 28 September 2017

\section{Keywords:}

Anaerobic digestion, MAHB

reactor, seed loads, start-up

strategies

\begin{abstract}
A B S T R A C T
The startup and performance of $58 \mathrm{~L}$ modified anaerobic hybrid baffled (MAHB) reactor operated under mesophilic conditions $\left(35^{\circ} \mathrm{C}\right)$ were investigated. The performance data of MAHB reactor and its influence of seed loads and start up process with regards to chemical oxygen demand (COD) removal by using various seed arrangement are compared. Three different seed loads were evaluated. Similar start up strategies were adopted in all systems, using a constant hydraulic retention time (HRT) of 4 days and influent chemical oxygen demand (COD) concentration of $750 \mathrm{mg} / \mathrm{L}$. This present study was done to compare the result for COD removal, $\mathrm{pH}$, methane concentration, and solid content in terms of volatile suspended solids (VSS) at three different start up. Start up 3 shows better reactor performance with highest COD removal (87\%), stable system $\mathrm{pH}$, and higher methane content (> $65 \%$ ). At the end of experiment, methanogen bacteria were observed in the MAHB reactor using autofluorescene microscope and scanning electron microscope (SEM) identification. Population of most probably Methanosarcina, Methanasaeta and Methanobacterium were present in the MAHB reactor which are responsible to produce methane in the system.
\end{abstract}

\section{INTRODUCTION}

Successful start-up of anaerobic reactors is an important indication for a stable operation and high removal efficiencies within a shorter possible time $[1,2]$. Variety of bacteria groups during start up process may cause unbalance and hence contributes to reactor failure. Few factors were extremely important in getting successful start-up such as biomass activity, growth rate, volume of inoculum, size and properties of granules, loading rate, hydraulic retention time (HRT) and mixing characteristics, environmental parameters ( $\mathrm{pH}$ and temperature) and finally wastewater, composition, strength and fluctuation in these parameters. Therefore, to achieve an optimum start up strategy can be a time consuming and complex process $[3,4]$. The fluctuations in external parameters such as temperature, HRT and $\mathrm{pH}$ should be avoided while organic loading rates (OLR) should be consistent throughout the process.

Adequate seeding is crucial since anaerobic bacteria may undergo slow growth process which leads to a long start up process. Considerable literatures are available on the start-up due to the need to develop sludge with certain properties, especially good settle ability. However, extensive variation is seen in the time taken for the sludge agglomerates to appear. Anaerobic responses to seed volume depend on many factors such as presence of toxic materials, activity of the biomass, characteristics of the seed and duration of overloading $[5,6]$. The imbalance or upset of the reactor usually occurred due to the complexity of microbial interactions that involved. A build up on the residual chemical oxygen demand (COD) concentration owing to volatile acid (VFA) accumulation is one of the most common symptoms that caused by the overloading of organic. This in which can leads to inhibition of methane production (acidosis) [5, 7].

An active methanogens biomass with high digesting capacity were develop in order to determine the importance of seeding concentration on reactor start up and to monitor certain key parameters such as solids loss and floc size that had not been monitored yet. Apart from that, reactor configuration also plays a significant role during anaerobic start up. Hence, a novel MAHB reactor which is a combination of regular suspended growth systems and fixed biofilm together with the modification of baffled-reactor configurations has been developed. Each different modified baffles have its own characteristics (form/shape) to assist a better contact and superior mixing of wastewater and anaerobic microorganisms [2]. Furthermore, literature survey designates that treatment of effluents that released from recycled paper mills have not been reported using MAHB reactor.

The objectives of this present work are to investigate whether different seed loading could enhance the MAHB reactor performance and to explore the ability of the reactor to handle different seed ratio. For that reason, the main operating parameters studied includes COD removal efficiencies, system $\mathrm{pH}$, total volatile fatty acids (VFA) concentration, solids analysis, and reactor performance at each steady state. The bacterial morphology also was observed at each steady state condition.

\section{METHODOLOGY}

\subsection{Modified anaerobic hybrid baffled reactor}

Five compartments with total active volume of 58 litres lab scale modified anaerobic hybrid baffled (MAHB) reactor was used in this study. The sampling ports were located at the top and bottom of each compartment, and the reactor were maintained at room temperature using a water bath. Polypropylene pall rings were used as a media to support the formation of biofilm which located under surface of compartment two and three.

\subsection{Sampling and analysis}

Samples were collected from each compartment as well as with final effluent from the system for analysing purpose. For each start up, the MAHB reactor were assigned with a unique strategy for seeding process. The seeding arrangement is a combination of Palm Oil Mill Effluent (POME) sludge with RPME wastewater as shown in Table 1.

Table 1: Seeding arrangement for different start up process 


\begin{tabular}{|c|c|c|c|c|}
\hline $\begin{array}{l}\text { Start } \\
\text { Up }\end{array}$ & $\begin{array}{l}\text { Operation } \\
\text { Time (day) }\end{array}$ & $\begin{array}{l}\text { OLR } \\
\text { (g COD/L day) }\end{array}$ & $\begin{array}{l}\text { HRT } \\
\text { (day) }\end{array}$ & Seeding Arrangement \\
\hline \multirow[t]{2}{*}{1} & $1-10$ & - & - & $10 \%$ POME sludge \\
\hline & $11-27$ & 0.25 & 4 & $\begin{array}{l}10 \% \text { RPME of total volume added daily unti } \\
\text { full }\end{array}$ \\
\hline \multirow[t]{2}{*}{2} & $1-3$ & - & - & $10 \%$ POME Sludge \\
\hline & $4-20$ & 0.20 & 4 & $\begin{array}{l}30 \% \text { RPME of total volume added daily unti } \\
\text { full }\end{array}$ \\
\hline \multirow[t]{2}{*}{3} & $1-10$ & - & - & $30 \%$ POME Sludge \\
\hline & $11-28$ & 0.20 & 4 & $\begin{array}{l}30 \% \text { RPME of total volume added every two } \\
\text { days until full }\end{array}$ \\
\hline
\end{tabular}

MAHB reactor operation was monitored through VFA concentration, $\mathrm{pH}$, COD removal, solids wash out, particle size distribution and gas production. Analytical techniques such as $\mathrm{pH}$ and solid concentration (VSS) were based on Standard Methods while floc size was measured using Malvern Particle size Analyser model 2000 [8]. Samples were collected using a specially adapted wide-tipped pipette to avoid any breakage of microbial flocs. Triplicate samples were prepared for each parameter reading to increase the accuracy of the results, and only average value was reported throughout this study. The repeatability of the analysis data was found to be sufficiently high with relative error between repeated runs less than 5\%. Biogas composition was determined using Shimadzu Gas Chromatography - Flame Ionization Detector (GC-FID) with prepack N column. Carrier gas was helium set at a flow rate of $50 \mathrm{~mL} / \mathrm{min}$, column temperature of $28^{\circ} \mathrm{C}$, detector temperature of $38^{\circ} \mathrm{C}$ and injector temperature of $128^{\circ} \mathrm{C}$.

VFAs were determined using esterification methods, while COD was measured using Spectrophotometer DR-2800 according to the reactor digestion method(Jirka and Carter 1975). Scanning electron Microscope (SEM) and Fluorescence Microscopy were used to examine the microbial population involved. Sludge sample from each compartment were taken and examined in SEM according to standard protocols and were produced at magnifications between $5 \mathrm{k}-10 \mathrm{k}$ [9].

\section{RESULT AND DISCUSSION}

\subsection{COD Removal Efficiency}

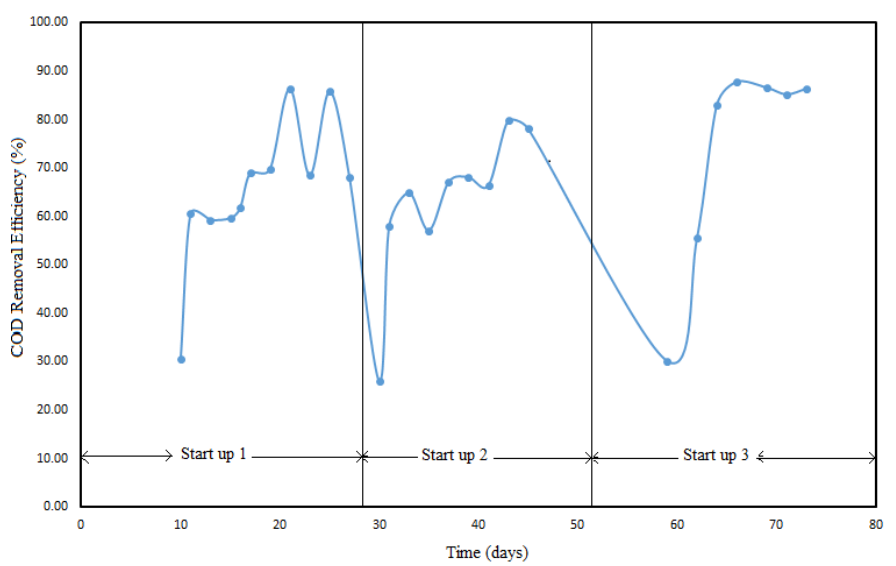

Figure 1: COD removal efficiency in MAHB reactor at different start up strategies

MAHB reactor shows stable performance for each start up period. Overall process took about 75 days to complete all 3-different start up where the startup process for all three-different seed loading achieved stable performance regarding the COD removal and methane production rate in less than 30 days. However, extra attention should be focused on their changes in removal efficiencies (Figure 1) and performance behaviors. The fluctuating removal efficiencies were recorded as continuous feeding started for each start up. During each start up period, an increase in COD removal efficiency was observed where highest removal efficiencies were recorded in startup 3of value of $87 \%$. The results show similarities with the research work reported by a researcher [10]. They found out that more than 85\% COD removal were achieved during start-up period. High COD removal indicates that the organic matter in the supernatant was hydrolyzed by microorganisms available that grow well from the provided seed until the number of microbes become limited to digest further the organic matter. Start-up 3 was accomplished after 28 days of continuous operation (day 73) with a subsequent stable performance [2].

The early variations in COD removal efficiency in all three start up were due to overloading slower methanogens and environmental conditions favoring acidogenic bacteria. The fluctuating efficiencies are clear in first

two start up before it reached stabilization in startup 3. This indicates that the MAHB reactor has a good potential for treating RPME wastewater at ambient temperature.

The design of MAHB reactor itself contributes to the high removal of COD. The hanging and standing baffles that were bent $3 \mathrm{~cm}$ above the reactor's base at a $45^{\circ}$ angle route the flow to the center of the up comer, thus allowing for better contact and biosolid mixing at the base of each compartment [2]. The advantage of this design is that the liquid flow makes repeated passes through the sludge, ensuring good contact between liquid and solid and reducing bypassing of the sludge [11].

Hence, the microorganisms able to decompose complex organic substances into simple, chemically stabilized compounds mainly methane and CO2 effectively. Furthermore, this hybrid system (attached and suspended growth system) was better compared to conventional system. The difference is due to the existence of the biofilm in the hybrid reactors and these results confirm the competence of the hypotheses and agree well with data from the literature [12-14].

\subsection{System $\mathrm{pH}$ and total VFAs present in reactor for different start up strategies}

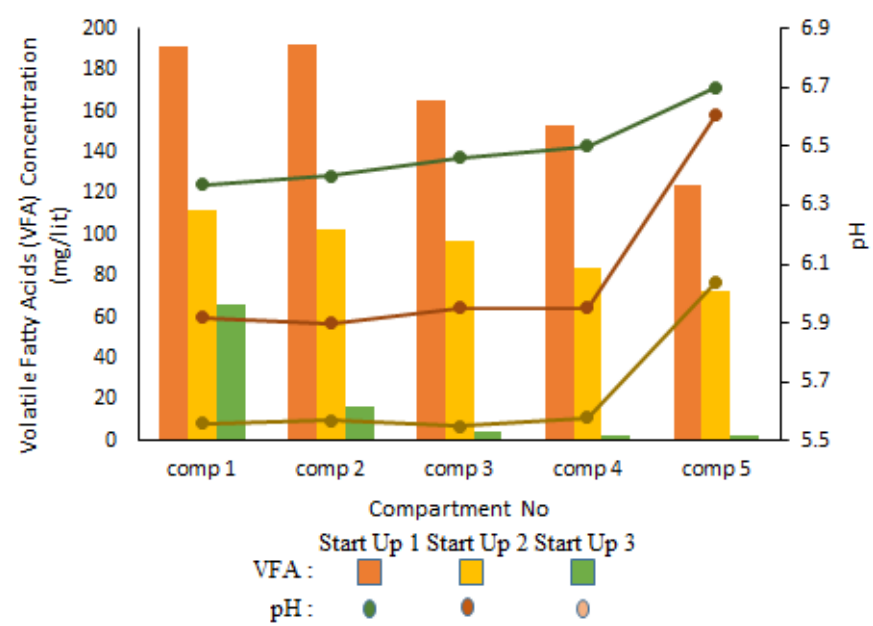

Figure 2: Volatile fatty acids (VFA) concentration and system $\mathrm{pH}$ for different start up

Figure 2 illustrated concentration of volatile fatty acids (VFA) and system $\mathrm{pH}$ found in each compartments of different start up (start up 1, 2 and 3). High level of VFA concentration (191 - $66 \mathrm{mg} / \mathrm{L})$ and slightly lower $\mathrm{pH}$ values in between 5.9 to 6.37 in front compartment were noted for each start up 1, 2 and 3, respectively. This might be due to high activity of hydrolytic and acidogenic bacteria compared to methanogenic bacteria. The later compartments show lower VFA concentrations (decreased from 192 to $124 \mathrm{mg} / \mathrm{L}$ ) and increasing $\mathrm{pH}$ up to $\mathrm{pH}$ of 6.7 in compartment 5 . This is due to high activity of methanogenic bacteria producing methane. This indicates the different microenvironments select the dominant bacteria population. The similar behaviour was noted for all start up 1,2 and 3 .

It was observed that for each start up strategies, the VFA in first three compartments dropped rapidly, while other compartments (compartment 4 and 5) were found to be the least affected. This phenomenon indicates accumulation of fatty acids in first three compartments while methanogenesis occurred in later compartments. This was due to the fact that the hydrolysis, acidogenesis and acetogenesis dominantly occurred in the initial chambers $[12,15]$.

Result shows that $\mathrm{pH}$ profiles were uniformly below 7 for each start up in the whole system. It was observed that $\mathrm{pH}$ value was slightly constant in front compartment which designates the effective consumptions of volatile acids by methanogens. The earlier compartments had lower $\mathrm{pH}$ as acidogenesis and acetogenesis occurred in these compartments [16]. Thus, due to the high concentration of volatile fatty acids (VFAs), the sudden drop in the $\mathrm{pH}$ ( $\mathrm{pH}$ of 5.92 to 6.37), especially in the first compartment is quite noticeable. Fig. 3 shows that the $\mathrm{pH}$ in the first compartment was the lowest. The $\mathrm{pH}$ values increased along the reactor to $\mathrm{pH}$ of $6.61,6.04$ and 6.70 for each start up 1, 2 and 3, respectively due to the conversion of intermediate products, i.e. the VFAs in the latter compartments which also contributes to a high methanogenic activity $[17,18]$.

This increase happened because COD removal increased up to $85 \%$ which means no sufficient food was left for microorganisms to survive. 
Similar trend results were reported by some researcher which are supported by an increased pattern of MLVSS loss [19,20]. Furthermore, the environmental change for these bacteria from the original environment to the new environment of the anaerobic digester can explain the steep decrease of the microorganisms in general and these methane-forming bacteria in specific, during the start-up period [21]. These methane-forming bacteria are oxygen-sensitive, fastidious anaerobes and are free-living terrestrial and aquatic organisms. Although these bacteria are oxygen sensitive, this is not a significant disadvantage where it is usually found in habitats that are rich in degradable organic compounds. Through microbial activity, a rapid removed of oxygen occurred in this habitat [22].

From the data obtained, it shows that start up 3 have more stable VFA and $\mathrm{pH}$ variation which indicates better performance of the MAHB reactor in terms of methanogenic activity. This is proving by high $\mathrm{pH}$ value and quite low VFA concentration $(<10 \mathrm{mg} / \mathrm{L})$ at the rear end of the MAHB reactor that provides superior environmental condition for methanogenic bacteria to become more active in converting acetate and hydrogen to methane. This data is supported from previous study [2].

\subsection{Solids analysis at different start up}

The cumulative volatile suspended solids (VSS) wash out for each compartment for different start up is shown in Figure 3.

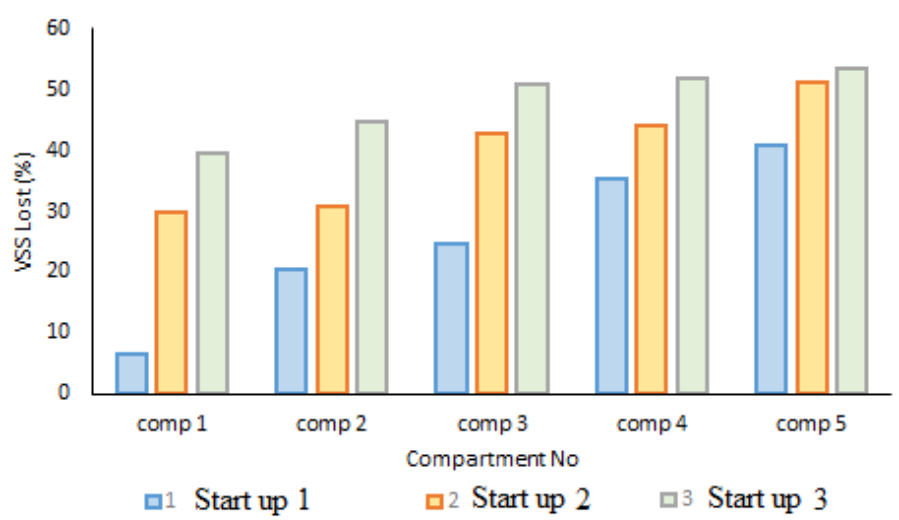

Figure 3: Cumulative volatile suspended solids (VSS) lost against different start up

Overall, highest VSS lost were recorded in compartment 5 and the lowest in compartment 1 . Compared to different start up strategies, start up 3 shows highest VSS lost compared to other two. A sharp increase in VSS lost for start-up 3 were in response to an increment of seeding arrangement and influent concentration compared to lower VSS lost in both start up 1 and 2. Similar parameters should be affecting solid loss as those described for floc size. Washout of large amount of biomass more than $40 \%$ cannot be allow since increases in methane gas production and subsequent improvements of reactor performance invariably delayed.

This means too much biomass washout can disturb or inhibited the growth process of the biomass particles or granules which are the key factor for microbial population inside the MAHB reactor [23]. In start-up 3 , an increased in washout were attributed to the observed increased in methane production and high concentration of seeding arrangement. The washout of biomass seems to be controlled by increased gas mixing. Although the VSS lost were highest in start-up 3, based on the result, start up 3 gave better performance in terms of methane content and COD removals efficiency compared to start up 1 and 2. Furthermore, the VSS lost for each start up not more than $50 \%$ after 80 days of operation.

\subsection{Reactor performance at steady-state for different start up}

At the end of start-up 1, COD removal efficiency was in a range of $61-69$ $\%$ for almost one week. This indicated that the reactor could be operated continuously until it reached steady state condition. The RPME wastewater was pumped into the MAHB reactor with an increased in seeding arrangement. For every change in seeding arrangement, various parameters were monitored until reached steady state (defined by constant COD values in the effluent for 4 days) condition. COD removal efficiency, $\mathrm{pH}$, methane production rate, alkalinity and floc size at steady state condition were shown in Table 2.

Table 2: Steady State Analysis for Different Start Up of MAHB Reactor

\begin{tabular}{|c|c|c|c|c|c|c|}
\hline & & pH & $\begin{array}{l}\text { COD } \\
\text { Removal } \\
\text { (\%) }\end{array}$ & $\begin{array}{l}\text { Methane } \\
\text { Production (L/day) }\end{array}$ & Alkalinity & Floc Size $(\mu \mathrm{m})$ \\
\hline \multirow{7}{*}{ Start Up 1} & In & 6.82 & - & & 165 & - \\
\hline & Comp 1 & 5.92 & 63.37 & & 150 & 105.9 \\
\hline & Comp 2 & 5.90 & 63.57 & & 163 & 126.2 \\
\hline & Comp 3 & 5.95 & 63.62 & 0.0566 & 172 & 132.6 \\
\hline & Comp 4 & 5.95 & 61.22 & & 200 & 175.4 \\
\hline & Comp 5 & 6.61 & 69.92 & & 200 & 157.6 \\
\hline & Eff & 7.18 & 68.12 & & 150 & - \\
\hline \multirow{7}{*}{ Start Up 2} & In & 6.23 & - & & 203 & - \\
\hline & Comp 1 & 5.56 & 69.24 & & 185 & 114.1 \\
\hline & Comp 2 & 5.57 & 69.33 & & 170 & 136.7 \\
\hline & Comp 3 & 5.55 & 68.89 & 0.2042 & 165 & 156.9 \\
\hline & Comp 4 & 5.58 & 69.46 & & 160 & 207.1 \\
\hline & Comp 5 & 6.04 & 77.90 & & 175 & 189.2 \\
\hline & Eff & 7.4 & 78.12 & & 155 & \\
\hline \multirow{7}{*}{ Start Up 3} & In & 7.18 & - & & 94.167 & \\
\hline & Comp 1 & 6.37 & 69.03 & & 158.33 & 156.9 \\
\hline & Comp 2 & 6.40 & 80.62 & & 185 & 173.3 \\
\hline & Comp 3 & 6.46 & 85.30 & 0.7967 & 208.75 & 208.6 \\
\hline & Comp 4 & 6.50 & 85.75 & & 221.25 & 218.3 \\
\hline & Comp 5 & 6.70 & 87.10 & & 223.75 & 206.6 \\
\hline & Eff & 7.78 & 86.41 & & 236.25 & - \\
\hline
\end{tabular}

From the table, it could be seen that the COD removal efficiencies increased from $61-69 \%, 68-78 \%$ and $69-87 \%$ for start-up 1, 2 and 3 , respectively after each increased in seeding arrangement at steady state condition. During the first few days of start-up, the effluent obtained was quite turbid because some light suspended solids in the seed sludge had been washout. For start-up 1, COD concentration of the effluent quite high which resulted in low COD removal efficiencies and only $33.90 \%(0.0566 \mathrm{~L} \mathrm{CH} 4 /$ day) of methane was produced. This indicates that the volume of seed sludge was not enough to digest the substrate inside the RPME wastewater. However, with the increasing ratio of seed sludge in subsequent start up (start-up 2), a significant increase in COD removal efficiencies (as high as 78\%) and methane content ( $>0.2 \mathrm{~L} /$ day) were achieved. During start up 3, the MAHB reactor was able to remove as high as $87 \%$ of influent COD and produce biogas containing $70 \%$ (0.7967 LCH4/day) methane.

Figure 4 shows the top view of opened MAHB reactor at the end of start-up 3. Observation shows that a thick film was develop on the surface of polypropylene ring on second and third compartments which indicates that inoculated digested sludge was fully acclimatized and the reactor could be operated for further study. The biogas bubbles were also clearly observed between the polypropylene pall ring in compartment 2 and 3.

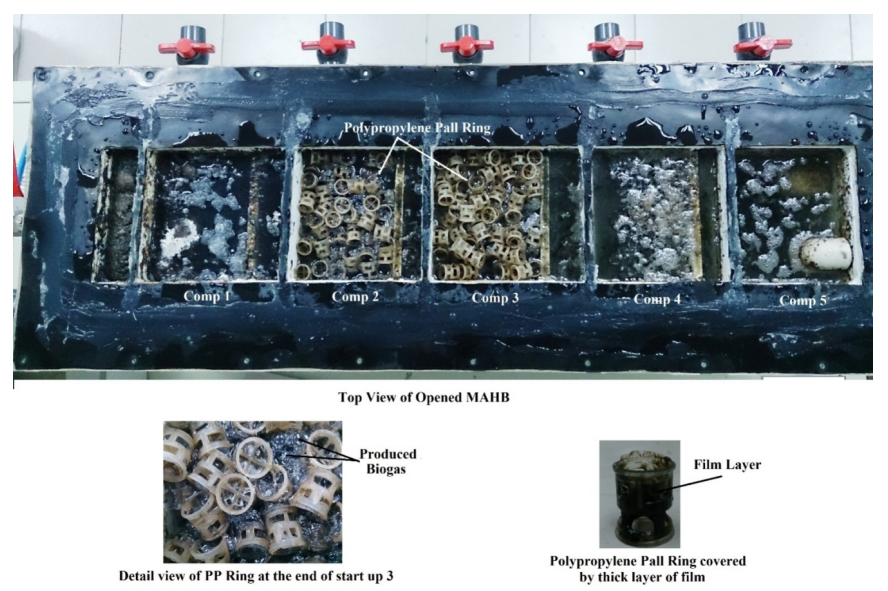

Figure 4: Thick film developed on the surface of polypropylene ring

During the experimental phase, the influent $\mathrm{pH}$ varied from 6.8 to 7.1, alkalinity from 90 to $200 \mathrm{mg} / \mathrm{L}$, while effluent $\mathrm{pH}$ and alkalinity were $7.1-7.8$ and 155 to $240 \mathrm{mg} / \mathrm{L}$, respectively as shown in Table 2. As the seeded ratio increased, the system $\mathrm{pH}$ in all five chambers remained at 5.5 - 7.0, which indicates that buffering capacity of RPME wastewater is satisfactory enough to neutralise the produced VFA during the anaerobic digestion. This is then capable to maintain the digestion liquor $\mathrm{pH}$ at the optimum value for methane-producing bacteria, thus guaranteeing the stable operation of the reactor. L/day) were achieved. During 
the anaerobic digestion. This is then capable to maintain the digestion liquor $\mathrm{pH}$ at the optimum value for methane-producing bacteria, thus guaranteeing the stable operation of the reactor.

Initial sludge inoculum had an average floc size of $92.805 \mu \mathrm{m}$. Increasing size may due to flocculation process where several small particles were combines to form larger floc that leads to granules formation. This clarification supported by report stating that proteinaceous feed may add to the polymers present in the MAHB reactor and encourages polymer bridging between particles. Results clearly demonstrate a considerable increase in floc size (Table 2) over time with an interesting profile through the MAHB reactor. However, the floc size was slightly decreased in compartments 5 due to possible washout and less nutrients at the rear end of the MAHB reactor. Compartment $1-5$ had floc size of average diameter of $105-160 \mu \mathrm{m}, 110-190 \mu \mathrm{m}$ and $150-210 \mu \mathrm{m}$ for start-up 1,2, and 3 respectively. This result were in comparison with previous result obtained by Barber and Stuckey. This indicates that start up strategy does affect the floc size profile in the MAHB reactor [19].

The results presented shows that the larger floc size was found in compartment 4 for each start up. The reduced floc size in front compartment may be attributed to high COD levels which result in high gas production and thus disrupt the flocs and reducing their size while the reduced size towards the rear ends of the MAHB reactor were due to low level of substrates, which results in low bacterial growth [19]. Subsequently, the floc size of the middle compartment (3 and 4) were attributed to sufficient substrate for bacterial growth and slightly lower gas production reduced effects of gas breakage. Similar floc size profiles were recorded by Barber and Stuckey [9]. From the result obtained, it is concluded that start up 3 provide better performance in terms of COD removal efficiencies, $\mathrm{pH}$, alkalinity, floc size and methane content since it has the highest ratio of seeds during the acclimatization process.

\subsection{Bacterial Morphology}
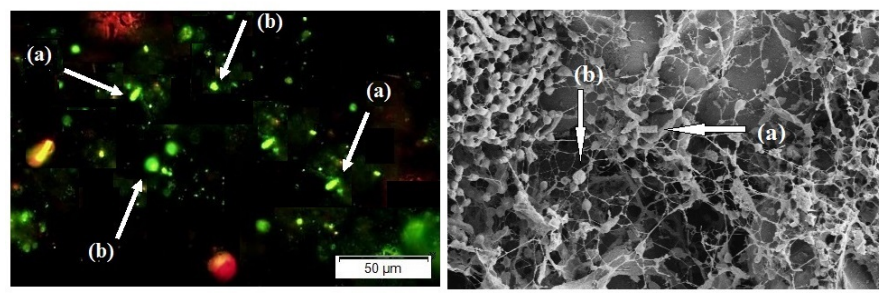

Figure 5: Fluorescene microscopy and SEM image of microbial consortia in compartment 1 of MAHB reactor. (a) Methanobacterium sp like bacteria (Rod shape), and (b) Methanosarcina or Methanococcus sp like bacteria (Cocci shape) Methanococcus sp like bacteria (Cocci shape)

From the steady state evaluation of each start up seeding strategies, start up 3 is chosen as the optimal seeding arrangement that leads to better performance and stable MAHB reactor. Hence, for bacterial morphology observation, fluorescent and scanning electron microscope images from compartment 1 (Figure 5) and compartment 5 (Figure 6) of MAHB reactor were taken at the end of startup 3 . Methanogenic bacteria can be identified on the basis of their autofluorescence behaviour under ultraviolet illumination. All the methanogenic bacteria observed exhibited autofluorescence, although the rate at which the fluorescence faded varied from species to species. The autofluorescence colour of methanogenic bacteria includes light green, blue green, blue and red in colour as supported from previous research work [25,26].

The uniqueness of MAHB reactor construction has contributes to the various profiles of microbial communities present within each compartment. The type and amount of substrate present, as well as external parameters such as $\mathrm{pH}$ and temperature also affect the population distribution of microorganisms within the reactor [27]. Within the first front compartment (acidification zone), the fast-growing bacteria which capables to grow at high substrate levels and reduced $\mathrm{pH}$ was dominant.

Previous findings by Changsoo, 2009 proved that Methanosarcina sp (with higher growth rate) outcompete at a high acetate concentration $(>1$ mmol), whereas Methanosaeta sp (with higher substrate affinity) grow favourably well at a low acetate concentration $(<1 \mathrm{mmol})$ [1]. Thus, in most cases, Methanosarcina sp were responsible for methane production under harsh condition due to its fast doubling times and grow well at near neutral $\mathrm{pH}$. Figure 5 represents spherical cells which most probably belong to either Methanosarcina sp or Methanococcus sp (yellow/light green) where having similarity in morphology and kinetic abilities. Proportions of rods seen probably were of acid producing bacteria. Previous researches, Malakahmad recorded that large populations of
Methanobacterium sp (light blue green) were present at the front of a hybrid baffled reactor [28]. At the front compartment, the growth of these hydrogen scavenging methanogens were stimulated by elevated levels of headspace hydrogen present. Literature survey appraised that most of active biomass inside hybrid baffled reactor were found at the bottom of each compartment with compartment 1 recorded the highest levels [29]. These discoveries were in comparisons with faster growing bacteria in the leading compartments.
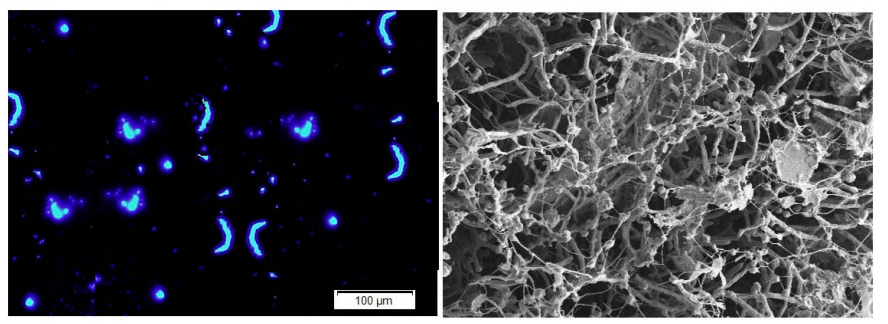

Figure 6: Fluorescene microscopy and SEM image of microbial floc in compartment 5 . The flocs seem to be formed of filamentous microbes of Methanosaeta sp.

Using scanning electron microscopy (SEM), a presumptive naming can be done based on structural characteristics, inclusions shape, and, etc. In compartment 1, from fluorescent microscopy and SEM image (Figure 5) shows a variety of microorganism present within the reactor. This is mainly due to the nature of the substrate influent. Observed morphology includes cocci, bacilli, and rods but lack of filamentous Methanosaeta like bacteria (weekly blue in colour). The denoted coccus shape microorganism might be methanococcus sp as it is comparable with the observed population reported by Pillay [30]. The overwhelming numbers of bacteria observed in compartment 5 (Figure 6) were long tubular filaments and lengths of divided rods. Hence, in compartment 5, SEM image shows that most of the microbe's present might be filamentous Methanosaeta sp. Due to low substrate levels and slightly neutral $\mathrm{pH}$, it is suggested that these microbes were Methanosaeta $\mathrm{sp}$ which can have adapted to low acetate levels. The image of Methanosaeta were denoted using previous finding by Pillay and Lima for fluorescent and SEM image respectively by comparing the shape of the microbes in which is bamboo-shaped rods [30,31]. However, to confirm the species of present bacteria, further microbial identification such as rRNA gene sequences for phenotypically characterized methanogens can be done.

\section{CONCLUSIONS}

The present study shows that during start up 3, MAHB reactor successfully removed COD up to $87 \%$ with stable system $\mathrm{pH}$, and higher methane content $(>65 \%)$. It seems that the seed loading ratio is beneficial parameters to solve loading problem and gave better performance. Even though, this start up considered successful but more studies are needed to improve the methane production and system $\mathrm{pH}$. Maintaining a suitable and stable $\mathrm{pH}$ within the reactor should be a major priority for ensuring efficient methanogenic digestion.

\section{ACKNOWLEDGEMENT}

The authors acknowledge the financial support from the Universiti Sains Malaysia (RU-I A/C.1001/PJKIMIA/814148) and MyBrain 15 Scholarship (KPM(B) 870204115782).

\section{REFERENCES}

[1] Lee, C., Kim, J., Hwang, K., Vincent, O., and Hwang, S. 2009. Quantitative analysis of methanogenic community dynamics in three anaerobic batch digesters treating different wastewaters. Water Research, 43 (1), 157-165.

[2] Hassan, S. R., Zwain, H. M., Zaman, N.Q., Dahlan, I. 2013. Recycled paper mills effluent treatment in a modified anaerobic baffled reactor: start-up and steady-state performance. Environmental Technology, 35 (3), 294-299.

[3] Rajakumar, R., and Meenambal, T. 2008. Comparative Study on Start Up Performance of HUASB and AF Reactors Treating Poultry Slaughterhouse Wastewater. International Journal of Environmental Research, 2 (4), 401-410.

[4] Bakonyi, P., Nemestóthy, N., Simon, V., Bélafi-Bakó, K. 2014. Review on the start-up experiences of continuous fermentative hydrogen producing bioreactors. Renewable and Sustainable Energy Reviews 40, 806-813. 
[5] Stamatelatou, K., Vavilin, V., and Lyberatos, G. 2003. Performance of a glucose fed periodic anaerobic baffled reactor under increasing organic loading conditions: 1. Experimental results. Bioresource Technology, 88 (2), 131-136.

[6] Whittaker, C., Hunt, J., Misselbrook, T., and Shield, I. 2016. How well does Miscanthus ensile for use in an anaerobic digestion plant. Biomass and Bioenergy, 88, 24-34.

[7] Sterling J.R., Lacey, R. E., Engler, C.R., and Ricke, S.C. 2001. Effects of ammonia nitrogen on $\mathrm{H} 2$ and $\mathrm{CH} 4$ production during anaerobic digestion of dairy cattle manure. Bioresource Technology, 77 (1), 9-18.

[8] Rice, E. W, 2012. Standard methods for the examination of water and wastewater, Washington: American Public Health Association, American Water Works Association, Water Environment Federation.

[9] Diao, H. F., Li, X. Y., Gu, J.G., Shi H.I, Xic, Z.M. 2004. Electron microscopic investigation of the bactericidal action of electrochemical disinfection in comparison with chlorination, zonation and Fenton reaction. Process Biochemistry, 39 (11), 1421-1426.

[10] Vossoughi, M., Shakeri, M., and Alemzadeh, I. 2003. Performance of anaerobic baffled reactor treating synthetic wastewater influenced by decreasing COD/SO4 ratios. Chemical Engineering and Processing: Process Intensification, 42 (10), 811-816.

[11] Torabian, A., Abtahi, S.M., Amin, M.M., and Momeni, S.A. 2010. Treatment of Low Strength Industrial Wastewater. Iran Journal of Environmental Health Science and Engineering, 7 (3), 229-240.

[12] Hui-ting, L., and Yong-feng, L. 2010. Performance of a hybrid anaerobic baffled reactor (HABR) treating brewery wastewater. International Conference on Mechanic Automation and Control Engineering (MACE).

[13] Rongrong, L., Xujie, L., Qing, T., Bo, Y., and Jihua, C. 2011. The performance evaluation of hybrid anaerobic baffled reactor for treatment of PVA-containing desiring wastewater. Desalination 271 (13), 287-294.

[14] Hassan, S.R., Zaman, N.Q., Dahlan, I. 2015a. Effect of organic loading rate on anaerobic digestion: Case study on recycled paper mill effluent using Modified Anaerobic Hybrid Baffled (MAHB) reactor. KSCE Journal of Civil Engineering, 19 (5), 1271-1276.

[15] Ge, S., Usack, J. G., Spirito, C.M., Angenent, L.T. 2015. Long-Term nCaproic Acid Production from Yeast-Fermentation Beer in an Anaerobic Bioreactor with Continuous Product Extraction. Environmental Science \& Technology, 49 (13), 8012-8021.

[16] Dama, P., Bell, J., Foxon, K.M., Brouckaert, C.J., Huang, T., Buckley, C.A., Naidoo, V., Stuckey, D. 2002. Pilot-scale study of an anaerobic baffled reactor for the treatment of domestic wastewater. Water science and technology, 46 (9), 263-270.

[17] Krishna, G. V. T. G., Kumar, P., and Kumar, P. 2007. Complex wastewater treatment using an anaerobic baffled reactor. Environmental Progress, 26 (4), 391-398.

[18] Zwain, H. M., Aziz, H. A., and Dahlan. 2017a. Performance of modified anaerobic inclining-baffled reactor treating recycled paper milleffluent: effects of influent chemical oxygen demand concentration and hydraulic retention time. Environmental Technology, 1 (1-9).

[19] Barber, W. P., and Stuckey, D. C. 1998. The Influence of Start-Up Strategies on the Performance of an Anaerobic Baffled Reactor. Environmental Technology, 19 (5), 489-501.

[20] Alrawi, R.A., Ahmad, A., Ismail, N., Kadir, M.O.A. 2010. Methane production during start-up phase of mesophilic semi- continues suspended growth anaerobic digester. International Journal of Chemical Reaction Engineering 8, 1542-6580.

[21] Zwain, H. M., Aziz, H. A., Ng, W.J., and Dahlan, I. 2017b. Performance and microbial community analysis in a modified anaerobic incliningbaffled reactor treating recycled paper mill effluent. Environmental Science and Pollution Research, 24 (14), 13012-13024.

[22] Gerardi, M. H. 2003. Methane-forming Bacteria. The Microbiology of Anaerobic Digesters, John Wiley \& Sons, Inc. 17-29.

[23] Habeeb, S. A., Latiff, A.B.A.A., Zawawi, D., Zulkifli, D. 2011. A review on granules initiation and development inside UASB Reactor and the main factors affecting granules formation process. International Journal of Energy and Environment. 2 (2), 311-320.

[24] Jirka, A. M., and Carter, M. J. 1975. Micro semiautomated analysis of surface and waste waters for chemical oxygen demand. Analytical Chemistry, 47 (8), 1397-1402.

[25] Doddema, H. J., and Vogels, G. D. 1978. Improved Identification of Methanogenic Bacteria by Fluorescence Microscopy. Applied and Environmental Microbiology, 36 (5), 752-754.

[26] Stabnikova, O., Liu, X. Y., Wang, J.Y., and Ivanov, V. 2006. Quantification of methanogens by fluorescence in situ hybridization with oligonucleotide probe. Applied Microbiol Biotechnology, 73 (3), 696-702.

[27] Hassan, S.R., Zaman, N.Q., Dahlan, I. 2015b. Microscopic Observation of Anaerobic Microorganism in a Modified Anaerobic Hybrid Baffled (MAHB) Reactor in Treating Recycled Paper Mill Effluent (RPME). Journal of Engineering Research and Technology, 2 (1), 61-64.

[28] Malakahmad, A., Zain, S. M., Basri, N.E.A., Kutty, S.R.M., and Isa, M. H. 2009. Identification of Anaerobic Microorganisms for Converting Kitchen Waste to Biogas. World academy of science, engineering and technology, $60,1336-1341$

[29] Bell, J. 2002. Treatment of Dye Wastewaters in the Anaerobic Baffled Reactor and Characteristics of the Associated Microbial Populations. School of Chemical Engineering. Durban, Universiti of Natal. $\mathrm{PhD}$ in Engineering.

[30] Pillay, S., Foxon, K., Rodda, N., Smith, M.T., and Buckley, C.A. 2004. Microbiological studies of an anaerobic baffled reactor (ABR). ResearchGate, 1-11.

[31] Lima, C. A. A., Ribeiro, R., Foresti, E., and Zaiat, M. 2005. Morphological study of biomass during the start-up period of a fixed-bed anaerobic reactor treating domestic sewage. Brazilian Archives of Biology and Technology, 48 (5), 841-849. 